\title{
Jual Beli Pakaian Bekas dalam Perspektif Fikih Muamalah Iqtishodiyah
}

\author{
Ahmad Fauzi \\ Program Studi Hukum Ekonomi Syariah, Fakultas Syariah, \\ Institut Agama Islam Al-Qolam \\ Email: afauzi1003@gmail.com
}

\begin{abstract}
In the life of the world, Islamic law provides insight into economic policies. Many in everyday life people meet their lives by doing business. In economics, business is an organization that sells goods or services to consumers or other businesses for profit. This study aims to conduct an in-depth analysis related to buying and selling used clothing in the perspective of fiqh muamalah iqtishodiyah. This research is qualitative by using the documentation method in data collection. The conclusion of this research is that buying and selling used clothing does not violate the Sharia rules, but raises several negative aspects that need to be considered, namely aspects of health, cleanliness and termination of employment in the clothing production industry.
\end{abstract}

Keywords: Islamic law, clothing industry, employment. 


\section{Pendahuluan}

Seiring dengan perkembangan zaman, timbul pula di dalamnya suatu persoalan baru dalam dunia usaha (bisnis) serta ekonomi dan keuangan yang belum pernah dikenal oleh orang terdahulu bahkan yang hampir mendekati masanya. ${ }^{1}$

Mengenai masalah jual beli, kita juga harus mengetahui tentang adanya hukum-hukum dan aturan-aturan jual beli sendiri itu seperti apa, apakah jual beli yang dilaksanaka sudah sesuai dengan hukum Islam atau belum. Oleh karena itu, seseorang yang melaksanakan dunia usaha harus memahami dan mengetahui hal-hal yang berhubungan dengan jual beli sah atau tidak. Islam juga mengajarkan bahwa hubungan manusia dalam masyarakat harus dilakukan atas dasar pertimbangan yang mendatangkan kemaslahatan bagi manusia dan menghindarkan kemudharat.

Menurut ulama Hanafiyah jual beli adalah pertukaran harta (benda) dengan harta yang berdasarkan cara khusus (yang dibolehkan). ${ }^{2}$ Adapun perwujudan dari mu'amalat yang dibenarkan oleh Islam adalah jual beli. Menurut bahasa, bai' ialah tukar menukar

\footnotetext{
${ }^{1}$ Muhamad, Manajemen Kenangan Syariah, Cet. II (Yogyakarta: UPP STIM YKPN, 2016), 17.

2 Alaudin Al-kasyani, Badai' Ash-Shana'ifi Tartib Asy-Syara'I, juz v. 133.

236 Vol. 4, No. 2, September 2019
} 
sesuatu yang lain. Dalam pertukaran ini, akan masuk pertukaran sesuatu yang dianggap sebagai mal/harta. Adapun menurut syara' definisi terbaik yang pernah diungkapkan adalah bahwa ba'i adalah menyerahkan hak kepemilikan suatu barang yang berharga dengan cara barter/penukaran yang telah mendapatkan persetujuan syara'atau menyerahkan hak kepemilikan suatu manfaat yang mubah,secara permanen dengan ganti suatu harta yang berharga.

Didalam kehidupan bermu'amalah memberikan pandangan mengenai kebijakan perekonomian. Banyak dalam kehidupan seharihari masyarakat memenuhi kehidupannya dengan cara berbisnis. Didalam ilmu ekonomi, bisnis merupakan suatu organisasi yang menjual barang atau jasa kepada konsumen atau bisnis lainnya untuk mendapatkan laba.

Salah satu berbisnis usaha yang banyak dilakukan oleh masyarakat adalah jual beli. Jual beli ialah menukar harta dengan harta. Di kota Malang transaksi jual beli sering dilakukan dan berpusat disebuah pasar yang sering disebut dengan pasar Comboran Malang. Pasar Comboran merupakan salah satu pasar yang menjual pakaian bekas yang teletak di kota Malang dan masyarakat yang berdatangan di pasar tersebut, baik dari kalangan masyarakat setempat maupun dari kalangan luar daerah. Oleh karena itu pasar ini merupakan pasar 
yang sering di kunjungi masyarakat dan banyak menjual barangbarang yang cukup lengkap, selain itu juga pasar Comboran terletak dikawasan Malang kota yang terdapat banyak toko-toko besar.

Di Indonesia sendiri banyak orang yang tidak dapat memenuhi kebutuhan hidupnya hal inilah yang memicu banyak orang yang cenderung membeli pakaian bekas dari pada pakaian baru. Kondisi seperti ini terjadi karena perekonomian yang belum memadai sehingga untuk memenuhi kebutuhan sehari-harinyapun sangat sulit apalagi untuk membeli sebuah pakaian baru.

Secara rasio barang bekas tidak terlepas dari sifat cacat selain melihat barang yang dijual pembeli membutuhkan tempat, sehingga melihat barangnya secara langsung dan mengidentifikasi kecacatan barang tersebut sesuai atau tidak dengan kekurangan barang yang dijual, karena cacat menurut bahasa apa-apa yang dapat menghilangkan kejadian suatu barang yang menyebabkan berkurangnya keaslian barang tersebut. ${ }^{3}$

Adapun barang bekas disini, yaitu suatu barang yang sudah di pakai atau sisa yang sebelumnya sudah di pakai. Pasar Comboran lantai 2 dan 3 terdapat beberapa kios yang menjual pakaian bekas

\footnotetext{
${ }^{3}$ Ahmad Azhar Basir, Azas-Azas Muamalah, (Yogyakarta: Fakultas UII, 1993),
} 83.

238 Vol. 4, No. 2, September 2019 
dengan harga yang relative murah. Pakaian bekas disini juga memiliki daya tarik tersendiri bagi masyarakat dengan kualitas pakaiannya yang bisa di bilang cukup baik. Berdasarkan pengamatan yang terjadi di Pasar Comboran penjual/pengecer yang membeli pakaian bekas dari salah pegadaian swasta yang ada di kota Malang, masih dalam keadaan karung (ball) yang masih diikat pakai tali dengan harga Rp.2.000.000 sampai 4.000.000 sekisaran berat $60-80 \mathrm{~kg}$, penjual/pengecer disini tidak mengetahui dengan kualitas atau kecacatan barangnya, dikarenakan penjual/pengecer tidak diperbolehkan memeriksa barangnya. Praktek jual beli pakaian bekas di Pasar Comboran antara pedagang dan pembeli dilakukan dengan sistem eceran, dimana harga perpotongnya berkisar Rp. 15.000 sampai Rp. 40.000. Pakaian bekas terkadang mengalami kerusakan pada bagian kancing dan kerahnya, pejual baru menyadari hal tersebut ketika pembeli memberitahunya.

Jual beli yang diperbolehkan oleh syara' ada tiga ketentuan barang yang diperjual belikan, (1) Dapat dilihat oleh pembeli. (2) Dapat diketahui sifat dan keadaanya, (3) Suci dan manfaat. Dalam jual beli harus memenuhi syarat-syarat jual beli, dan juga mengenai bentuk jual beli yang dilarang dalam islam maupun yang diperbolehkan, yang mana telah dibenarkan agama. Benda atau barang yang akan dijadikan objek harus memenuhi syarat-syarat yaitu: 
mengetahui barang yang diakadkan,bersih barangnya, dan apakah suci/najis barang tersebut. Tujuan adanya semua syarat tersebut antara lain untuk menghindari pertentangan diantara manusia, menjaga kemaslahatan orang yang sedang akad, menghindari jual beli gharar (terdapat unsur penipuan), dan lain-lain. ${ }^{4}$

Penelitian ini bertujuan untuk melakukan analisis mendalam terkait jual beli pakaian bekas dalam perspektif fikih muamalah iqtishodiyah.

\section{Landasan Teori}

\subsection{Pengertian Jual Beli}

Secara etimologi, jual beli diartikan sebagai pertukaran sesuatu dengan sesuatu yang lain. ${ }^{5}$ Kata lain dari al-bai' adalah asysyira; al-mubadah, dan at-tijarah. Berkenaan dengan kata at-tijarah, dalam QS. Fatir ayat 29 dinyatakan:

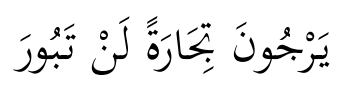

${ }^{4}$ Rachmat Syafe'i, Fikih Muamalab:( Bandung: Pustaka Setia, 2001), 76.

${ }^{5}$ Rachmat Syafe'i, Fikih Muamalah, (Bandung: Pustaka Setia, 2001), 73.

240 Vol. 4, No. 2, September 2019 
Artinya: "Mereka mengharapkan tijarah (perdagangan) yang tidak. akan rugi." (QS. Fatir: 29)

Adapun perbedaan jual beli menurut ulama Hanafiyah jual beli merupakan pertukaran harta benda dengan harta berdasarkan cara khusus yang dibolehkan. ${ }^{6}$

Jual beli menurut bahasa adalah tukar-menukar sesuatau dengan yang lain. Dalam pandangan ini, termasuk pertukaran sesuatu yang tidak dianggap sebagai mal/harta. Adapun definisi menurut syara' adalah menyerahkan hak kepemilikan suattu barang yang berharga dengan cara barter/pertukaran yang telah mendapatkan persetujuan syara' atau menyerahkan hak kepemilikan suatu mafaat yang mubah, secara permanen dengan ganti sesuatu harta yang berharga. $^{7}$

Dengan demikian penegertian secara menyeluruh jual beli merupakan tukar menukar harta benda atau jasa dengan lainnya yang dilakukan dengan cara suka sama suka yang dibenarkan hukum. Suka sama suka ini biasannya dilakukan ijab dan qobul atau serah terima antar penjual dan pembeli.

\footnotetext{
${ }^{6}$ Aludin Al-Kasyani, Badai' Ash-shanai' fi Tartib Asy-Syarai; juz V. 133.

7 Muhammad bin Qosim al-Ghazi, Fath al Qorib al-Mujib, juz 1, (Kediri: Zamzam Sumber Mata Air Ilmu, 2016), 294-297.
} 
Jual beli sendiri melibatkan antar dua belah pihak, dimana pihak yang satu menyerahkan uang untuk pembayaran barang yang diterima dan pihak yang lainnya menyerahkan barang sebagai ganti uang yang telah diterima, dalam hal ini harus sesuai dengan cara yang telah dibenarkan oleh syara'.

\section{Rukun dan Syarat Jual Beli}

Syarat dan rukun merupakan hal yang paling penting, sebab jual beli yang tidak memenuhi rukun dan syaratnya. Syarat merupakan sesuatu yang harus ada dalam jual beli tetapi tidak termasuk salah satu hakikat dalam jual beli itu sendiri. Sedangkan rukun adalah sesuatu yang merupakan bagian dari hakikat jual beli dan tidak terjadi jual beli tanpa terpenuhinya rukun tersebut. Jual beli dikatakan sah apabila unsur-unsur yang menyebabkan sahnya jual beli terpenuhi.

Menurut Imam Taqiyuddin: "Adapun rukun jual beli ada tiga: (1) Harus ada aqid (orang yang berakad terdiri dari penjual dan pembeli), (2) Shiqat yaitu ijab (penawaran) dan qobul (penerimaan), (3) Ma'qud Alaibi yaitu barang yang diakadka. 
Akan tetapi jumhur ulama menyatakan rukun jual beli ada empat, yaitu: ${ }^{8}$
a. Bai' (penjual)
b. Mustari (pembeli)
c. Shighat (ijab qobul)
d. Ma'qud (benda atau barang)

Adapun syarat-syarat jual beli yang sesuai dengan dengan rukun jual beli yang dikemukakan oleh jumhur ulama sebagai berikut: ${ }^{9}$

a. Syarat orang yang berakat

Para Ulama Fiqih sepakat menyatakan bahwa orang yang melakukan akad jual beli itu harus memnuhi syarat:

\section{1) Berakal}

Jual beli yang dilakukan anak kecil yang belum berakal, orang gila dan orang bodoh tidah sah hukumnya, Allah SWT berfirman:

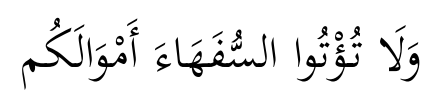

Artinya: "Dan janganlab kamu serabkan kepada orang-orang yang belum sempurna akalnya”. (QS. An-Nisa': 4)

${ }^{8}$ Nasrun Haroen, Op. Cit., 115.

${ }^{9}$ Ibid., 115. 
Adapun anak kecil yang mumayyiz, menurut ulama Hanafiyah, jika akad yang dilakukan membawa keuntungan bagi diri sendiri, maka akadnya sah. Sebaliknya, apabila akad itu membawa kerugian bagi dirinya, seperti meminjamkan harta kepada orang lain, mewakafkan, atau menghibahkannya, maka tindakan hukumnya tidak boleh dilaksanakan. Jumhur ulama berpendapat bahwa orang yang melakukan akad jual beli harus balig dan berakal. Apabila orang yang berkat belum balig dan berkal, jual belinya tidak sah, sekalipun mendapat izin dari walinya. ${ }^{10}$

2) Yang melakukan akad itu adalah orang yang berbeda. Artinya, seseorang yang tidak dapat bertindak dalam waktu yang bersamaan sebagai penjual, sekaligus pembeli. Misalnya, Ahmad menjual sekaligus membeli barangnya sendiri. Jual beli seperti ini tidak sah.

b. Syarat yang terkait dengan ijab dan qobul

Ijab qobul merupakan tindakan yang dilakukan oleh orang yang berakat, lafal akad berasal dari bahasa arab "Al-aqdu" yang berarti perikatan atau perjanjian dan pemufakatan "Al-ittifaq" secara termiologi fiqih, akad didefinisikan dengan: "pertalian ijab (pernyataan

${ }^{10}$ Nasrun Haroen, Op. Cit., 116.

244 Vol. 4, No. 2, September 2019 
melakukan ikatan) sesuai dengan kehendak syariat yang berpengaruh pada objek perikatan".

Maksudnya adalah seluruh perikatan yang dilakukan oleh kedua belah pihak atau lebih tidak dianggap sah apabila tidak sejalan dengan kehendak syara'. Seperti kesepakatan untuk melakukan riba, menipu orang lain, yang pada akhirnya pemindahan kepemilikan dari satu pihak kepihak yang lain, suatu akad dinyatakan sah apabila terpenuhinya syarat dan rukunya.

Selain syarat umum diatas, jual beli dianggap sah jika terpenuhi syarat-syarat khusus yang disebut dengan syarat ijab qobul sebagai berikut: ${ }^{11}$

1) Orang yang mengucapkannya telah balig dan berakal

2) Qobul sesuai dengan ijab

3) Ijab dan qobul dilakukan dalam satu majelis

c. Syarat barang yang diperjual belikan (Al-Mu'qud alaib)

1) Barang yang ada dalam kekuasaan penjual (milik sendiri)

Barang atau benda yang di perjualbelikan adalah milik seorang atau milik sendiri bukan milik orang lain. Barang yang sifatnya belum dimiliki seorang tidak boleh diperjual belikan seperti memperjual

${ }^{11}$ Ibid., 116. 
belikan ikan yang masih didalam laut atau burung yang masih dialam bebas, karena ikan dan burung itu belum dimiliki penjual.

Jika seseorang menjual harta orang lai dengan syarat jika pemilik barang itu suka, dan jika tidak suka jual beli dibatalkan, atau seseorang pembeli barang untuk orang lain tanpa persetujuannya, jual beli sah jika yang dibelikan suka. Jual beli semacam ini dalam ilmu fiqih disebut jual beli fudhul.

2) Barang yang jelas zatnya, ukurannya dan sifatnya (dapat diketahui)

Hendaknya yang menjual dan membeli mengetahui jenis barang dan harganya. Hal ini untuk menghindari kesamaran baik wujud, sifat dan kadarnya.

Jual beli yang mengandung kesamaran adalah salah satu jual beli yang diharamkan oleh Islam. Boleh menjual barang yang tidak ada ditempat akad dengan ketentuan dijelaskan sifatnya yang mengakibatkan ciri-ciri dari barang tersebut dapat diketahui. Jika barang tersebut sesuai dengan yang disepakati, maka wajib membelinya, tapi jika tidak sesuai dengan yang disifatkan maka dia mempunyai hak memilih untuk dilangsungkan akad atau tidak.

3) Barang yang dapat diserah terimakan 
Barang atau benda yang diserahkan pada akad yang berlangsung atau pada waktu yang telah disepakati bersama ketika transaksi berlangsung.

4) Suci bendanya

Barang yang tergolong najis bangkai, darah, dan daging babi. Para ulama sepakat tentang keharamannya. Namun memperbolehkan menjual setiap barang yang dapat dimanfaatkan bukan untuk tujuan memakannya dan meminumnnya.

5) Barang yang bermanfaat menurut syara’.

Pengertian barang yang dapat dimanfaatkan tentunya sangat relatif, sebab pada hakikatnya seluruh barang yang dijadikan objek jual beli merupakan barang yang dapat dimanfaatkan, seperti untuk dikomsumsi, dinikmati keindahannya seperti (bunga hiasan bunga), serta digunakan untuk keperluan yang bermanfaat seperti seorang membeli seekor anjing penjagaan.

Adapun maksud dari barang yang bermanfaat adalah kemanfaatan barang tersebut sesuai dengan ketentuan hukum agama (Syariat Islam). Maksudnya pemanfaatan barang tersebut tidak bertentangan dengan norma-norma agama. 
Hanya syarat dan rukun yang menyebabkan jual beli sesuai dengan syara'. Jika segala ketentuan-ketentuan tersebut tidak terpenuhi maka jual beli yang dilakukan tidak sah menurut hukum.

d. Syarat-syarat Nilai Tukar (Harga barang)

Terkait dengan maslah nilai tukar ini, para Ulama Fiqih membedakan ats-tsaman dengan as-si'r. Menurut mereka, ats-tsaman adalah harga pasar yang berlaku ditengah-tengah masyarakat secara actual, sedangkan as-si'r adalah modal barang yang seharusnya diterima para pedagang sebelum dijual ke komsumen. Dengan demikian, harga barang itu ada dua, yaitu harga antara pedagang dan komsumen (harga jual di pasar).

Oleh sebab itu, harga yang dapat dipermainkan para pedagang adalah ats-tsaman. Para ulam Fiqih mengemukakan syaratsyarat ats-tsman sebagai berikut: ${ }^{12}$

1) Harga yang disepakati oleh kedua belah pihak, harus jelas jumlahnya.

2) Boleh diserahkan pada waktu akad, sekalipun secara hukum, seperti pembayaran secara cek atau kartu kredit. Apabila barang itu dibayar kemudian (berutang), maka waktu pembayarannya harus jelas.

12 Ibid., 119.

248 Vol. 4, No. 2, September 2019 
3) Apabila jual beli itu dilakukan dengan saling menukarkan barang, maka barang yang dijadikan nilai tukar bukan barang yang diharamkan syara', seperti babi dan khamar karena kedua jenis benda ini tidak bernilai dalam syara'.

\section{Macam-Macam Jual Beli}

Jual beli berdasarkan pertukaran secara umum dibagi empat macam: $:^{13}$

a) Jual beli saham (pesanan)

Jual beli saham merupakan jual beli melalui pesanan, yakni jual beli dengan cara menyerahkan terlebih dahulu uang muka kemudian barangnya diantar setelahnya.

b) Jual beli muqoyadhah ( barter)

Jual beli muqoyadhah adalah dengan cara tukar menukar barang dengan barang, seperti menukar baju dengan sepatu.

c) Jual beli mutlak

Jual beli mutlak adalah jual beli barang dengan sesuatu yang telah disepakati sebagai alat pertukaran, seperti uang.

d) Jual beli alat penukar dengan penukar

${ }^{13}$ Al-Juhaili, Op.Cit., 595-596 
Jual beli penukar dengan alat penukar adalah jual beli barang yang biasa dipakai sebagai alat penukar dengan penukar lainnya, seperti uang perak dengan uang emas.

Berdasarkan segi harga, jual beli dibagi pula menjadi empat bagian:

a) Jual beli yang menggunakan (al-murababah)

b) Jual beli yang tidak menguntungkan, yaitu menjual dengan harga aslinya ( at-tauliyah)

c) Jual beli rugi (al-khasarah)

d) Jual beli al-musawah, yaitu penjual menyembunyikan harga aslinya, tetapi kedua orang yang akad saling meridhoi, jual beli seperti inilah yang berkembang sekarang.

\subsection{Hak Memilih (Khiyar) dalam Jual Beli}

Hak khiyar dalam Islam diperbolehkan, apakah dapat meneruskan atau mebatalkan jual beli nya, semua tergantung keadaan barang yang diperjual belikan. Adapun macam-macam khiyar dalam jual beli sebagai berikut:

a. Khiyar syarat

Khiyar syarat adalah hak pilih yang dijadikan syarat antar kedua belah pihak yakni penjual dan pembeli, atau salah seorang dari 
keduanya sewaktu akad terjadi penerusan atau pembatalan akad jual beli tersebut. Adapun batasan waktu ketetapan dalam memilih barang yaitu selama tiga hari tiga malam.

b. Kbiyar majlis

Khiyar majlis disini ialah hak pilih antar kedua belah pihak yang berakad untuk melangsungkan atau membatalkan akad, selama keduanaya tetap bearda dalam satu majlis dan belum berpisah.

c. Khiyar aib

Khiyar aib ialah hak untuk melangsungkan atau membatalkan jual beli antar kedua belah pihak yang melakukan akad apabila terdapat suatu cacat pada objek yang di jual belikan dan cacat pada barang tidak diketahui pemiliknya ketika sedang melakukan akad atau berlangsungnya akad.

Adapun syarat-syarat kbiyar ini agar dapat berlaku:

1) Pembeli tidak mengetahui bahwa barang tersebut ada cacat ketika berlangsungnya akad. Ketika dari awal pembeli sudah mengetahui adanya cacat pada barang yang dibeli, maka di situ tidak ada kbiyar aib.

2) Ketika akad berlangsung, penjual tidak mensyaratkan apabila ada cacat tidak bisa dikembalikan, yakni sudah ada kesepakatan dari pembeli tentang cacat yang ada pada barang 
yang akan dibeli. Jika penjual membuat kesepakatan antar pembeli, dimana barang yang dibeli tidak bias dikembalikan dalam kondisi apapun dan pembeli menyepakitinya, maka tidak ada khiyar aib.

3) Cacat tidak hilang sampai dilakukannya akad. Cacat yang ada pada benda yang di beli bukan akibat dari tindakan pembeli. Adapun juga pembeli tidak boleh berusaha untuk merubah atau menghilangkan cacat yang ada pada benda yang dibeli jika ditemukan cacat. Jika hal tersebut dilakukan, kbiyar aib batal.

Pembeli dapat menentukan sikapnya pada saat meihat barang tersebut, apakah ingin melangsungkan akad itu atau tidak. Khiyar atau haak milik itu dapat dibicarakan anatar penjual dan pembeli, seperti khiyar sifat. Apabila sifat-sifat yang telah disepakati bersam dalam suatu akad, tidak sesuai saat menerima barang, maka hak kbiyar ada pada pembeli, apakah akad itu diteruskan atau tidak dapat juag diganti kembali sesuai dengan sifat-sifat yang telah disepakati terdahulu. Tujuan khiyar ini adalah agar dalam jual beli tidak merugikan salah satu pihak, dan unsur-unsur keadilan serta kerelaan benar-benar tercipta dalam suatu akad transaksi jual beli. ${ }^{14}$

${ }^{14}$ M. Ali Hasan, Berbagai Macam kegiatan Dalam Islam, 141.

252 Vol. 4, No. 2, September 2019 


\subsection{Jual Beli yang Dilarang}

Menabung berasal dari kata dasar tabung yang memiliki arti celengan atau tempat menyimpan uang. ${ }^{15}$ Sedangkan "Menabung" adalah suatu perilaku menyimpan uang baik secara pribadi maupun kepada orang lain atau penyedia jasa layanan penyimpanan uang seperti bank, koperasi dan lainnya baik BUMN maupun swasta.

Jual beli yang dilarang dalam Islam sangatlah banyak. Jumhur ulama, hukum jual beli terbagi dua, yaitu jual beli sabih dan jual beli fasid, sedangkan menurut ulama hanafiyah jual beli terbagi tiga, jual beli sahih, fasad, dan batal.

Berkenaan dengan jual beli yang dilarang dalam Islam, wahbah Al-Juhalili meringkasnya sebagai berikut. ${ }^{16}$

\section{Terlarang Sebab Ahliah (Ahli Akad)}

Jual beli dikatagorikan sahaih apabila dilakukan oleh orang yang balig, berkal, dapat memilih, dan mampu bertasharruf secra bebas dan baik. Adapun mereka yang dipandang tidak sah jual belinya adalah berikut ini.

a) Jual beli orang gila

\footnotetext{
${ }^{15} \mathrm{KBBI}$, Op.Cit.

${ }^{16} \mathrm{Ibid}, .500-515$.
} 
Jual beli orang gila tidak sah. Begitu pula sejenisnya, seperti orang mabuk, sakalor, dan lain-lain.

b) Jual beli anak kecil

Jual beli anak kecil belum mumayyiz dipandang tidak sah, kecuali dalam perkara-perkara yang ringan atau sepele. Menurut ulama Syaf'iyah, jual beli anak mumayyiz yang belum balig, tidak sah sebab tidak ada ahliah. Adapun salah satu cara untuk melatih kedewasaan adalah dengan memberikan kekeluasan untuk jual beli, juga pengamalan atas firman Allah SWTT. :

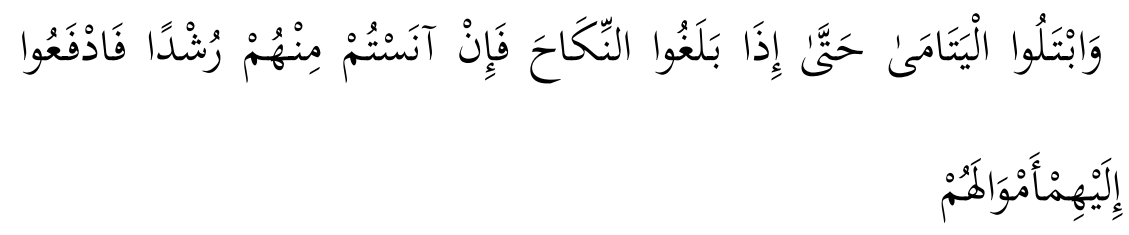

Artinya: Dan ujilah anak yatim itu sampai mereka cukup umur untuk kawin. Kemudian jika menurut pendapatmu mereka telah cerdas (pandai memelihara harta), maka serahkanlah kepada mereka harta-hartanya (QS. An-Nisa':6)

c) Jual beli orang buta

Jual beli orang buta tidak sah sebab ia tidak dapat membedakan barang yang jelek dan yang baik.

d) Jual beli terpaksa 
Jual beli orang terpaksa, seperti jual beli tanpa seizin pemiliknya, yakni yakni ditanggung mauquf. Adapun ulama Syafi'iyah, jual beli tersebut tidak sah sebab tidak ada keridhaan ketika akad.

e) Jual beli fudhul

Jual beli milik orang tanpa seiziin pemiliknya.Adapun ulama Syafi'iyah, jual beli fudhul tidak sah.

2. Terlarang Sebab Shighat

Jual beli yang didasarkan pada keridhaan diantara dua belah pihak yang melakukan akad, ada kesesuian diantara ijab dan qobul; berada disuatu tempat, dan tidak terpisah oleh sesuatu terpisah.

Adapun jual beli yang tidak memenuhi ketentuan tersebut dipandang tidak sah sebagai berikut:

a) jual beli mu'athah

Jual beli yang telah disepakati oleh pihak akad, berkenaan dengan barang maupun harganya, tetapi tidak memakai ijab-qobul.

b) Jual beli melalui surat atau melalui utusan

Jual beli melalui surat atau utusan adalah sah.Tempat berakad adalah samapainya surat atau utusan dari aqid pertama kepada aqid kedua.

c) Jual beli dengan syarat atau tulisan 
Disepakati kesahihan akad dengan isyarat atau tulisan khususnya bagi yang uzur sebab sama dengan ucapan.

d) Jual beli brang yang tidak ad ditempat akad

Jual beli yang tidak ada ditempat adalah tidak sah sebab tidak memenuhi syarat terjadinya akad.

e) Jual beli yang bersesuaian dengan ijab dan qobul

Menurut ulama Syafi'iyah menganggapnya tidak sah.

3. Terlarang Sebab Ma'qud Alaib (Barang Jualan)

Ma'qud alaih merupakan harta yang dijadikan alat pertukaran oleh orang yang akad, yang biasa disebut mabi' (barang jualan) dan harga.

Jual beli yang dianggap sah apabila ma'qud alaih adalah barang yang tetap atau bermanfaat, berbentuk, dapat diserahkan, dapat dilihat oleh orang-orang yang akad, tidak bersangkutan dengan milik orang lain, dan tidak ada larangan dari syara'.

Ada beberapa masalah yang disepakati oleh ulama diantaranya sebagai berikut:

a) Jual beli benda yang tidak ada atau yang dikwatirkan tidak ada

Jumhur ulama sepakat bahwa jual beli barang yang tidak ada atau dikwatirkan tidak ada adalah tidak sah. 
b) Jual beli barang yang tidak dapat diserahkan

Jual beli barang yang tidak dapat diserahkan, seperti burung yang ada di udara atau ikan yang ada di air tidak berdasarkan syara'.

c) Jual beli gharar

Jual beli gharar adalah jual beli barang yang mengandung kesamaran.

Menurut Ibd Jazi Al-Maliki, gharar yang dilarang ada 10 macam: $:^{17}$

(1) Tidak dapat diserahkan,

(2) Tidak dapat diketahui harganya,

(3) Tidak diketahui sifat barang dan harga,

(4) Tidak diketahui ukuran barang dan harga,

(5) Tidak diketahui jasa yang akan datang, seperti, "saya jual kepadamu, jika zaed datang."

(6) Mengharkan dua kali pada barang,

(7) Menjual barang yang diharapkan selamat,

(8) Jual beli hus'ha', misalnya pembeli memegang tongkat, jika tongkat jatuh, wajib membeli,

17 Al-Qawanin Al-Fiqhiyah, 256. 
(9) Jual beli munabadzah, yaitu jual beli denagan cara lemparmelempar, seperti seseorang melempar bajunya, kemudian yang lainpun melepar bajunya, maka jadilah jual bel,

d) Jual beli barang yang najis dan terkena najis

Ulama sepakat larangan jual beli barang yang najis, seperti khamar.

e) Jual beli barang yang tidak jelas

Jual beli seperti ini adalah fasid, sedangkan mnurut jumhur batal sebab akan mendatangkan pertentangan diantara manusia.

f) Jual beli barang yang tidak ada ditempat akad (gaib), tidak dapat dilihat

Jual beli seperti ini dibolehkan tanpa harus menyebutkan sifat-sifatnya, tetapi pembeli berhak khiyar ketika melihatnya. Ulama Syafi'iyah dan Hanabillah menyatakan tidak sah, sedangkan ualam malikiyah membolehkannya.

4. Terlarang Sebab Syara'

Ulama sepakat membolehkan jual beli yang memenuhi persyaratan dan rukunnya. Ada beberapa masalah diantaranya berikut ini:

a) Jual beli riba

b) Jual beli menggunakan uang dari barang yang diharamkan 
c) Jual beli barang dari hasil pencegatan barang

d) Jual beli pada waktu azan jum'at

e) Jual beli anggur untuk dijadikan khamar

f) Jual beli induk tanpa anaknya yang masih kecil

g) Jual beli barang yang tengah dibeli oleh orang lain

h) Jual beli memakai sayarat.

Menurut ulama Hanafiyah, sah jika syarat tersebut baik, seperti, "Saya akan membeli baju ini dengan syarat bagian yang ruak dijahit dulu." Sedangkan menurut ulama Syafi'iyah dibolehkan jika syarat maslahat bagi salah satu pihak yang melangsungkan akad. ${ }^{18}$

\section{Jual Beli Pakaian Bekas dalam Perspektif Fikih Muamalah}

\subsection{Pakaian Bekas}

${ }^{18}$ Rachmat Syafe'i, Fikih Muamalah, (Bandung: Pustaka Setia, 2001), 93-101 Iqtishodia : Jurnal Ekonomi Syariah 
Pakaian adalah bahan tekstil dan serat yang digunakan sebagai penutup atau pelindung tubuh. ${ }^{19}$ Pakaian juga dapat diartikan sebagai kebutuhan pokok manusia selain makanan, dan tempat tinggal atau tempat berteduh. Manusia membutuhkan pakaian untuk melindungi diri dan menutup tubuh. Namun seiring dengan perkembangan kehidupan manusia, pakaian juga digunakan sebagai simbol status, jabatan, ataupun kedudukan orang yang memakainya. Pakaian memiliki fungsi utama, yaitu untuk menjaga pemakainya merasa nyaman, pakaian melindungi bagian tubuh yang tidak terlihat, pakaian bertindak sebagai perlindungan dari unsur-unsur yang merusak, termasuk hujan, panas matahari, salju, dan angin. Pakaian juga mengurangi tingkat resiko selama kegiatan, seperti bekerja, atau berolahraga. Terkadang pakaian juga digunakan sebagai perlindungan dari bahaya lingkungan tertentu, seperti serangga, bahan kimia berbahaya, senjata, dan sebagainya. Bekas adalah tanda yang tertinggal atau tersisa (sudah dipegang, diinjak, dilalui, dan sebagainya). ${ }^{20}$ Dapat juga diartikan sebagai benda atau barang yang sudah dipakai oleh orang lain. Dari pengertian tersebut dapat disimpulkan bahwa

\footnotetext{
${ }^{19}$ A. A. Waskito, Kamus Praktis Bahasa Indonesia, Cet V, (Jakarta: Wahyu Media, 2009), 385.
}

${ }^{20} \mathrm{Ibid}$, hlm. 87

260 Vol. 4, No. 2, September 2019 
pakaian bekas adalah benda atau barang yang dipakai oleh seseorang untuk menutupi tubuhnya namun barang tersebut telah dipakai oleh orang lain. ${ }^{21}$

Adapun ciri-ciri dari pakaian bekas yang sering kita jumpai diberbagai toko pakaian memiliki ciri-ciri tersendiri, diantaranya adalah:

a) Bahan tipis, bahan yang tipis dan berserat merupakan salah satu bentuk yang sering ditemukan dalam produk pakaian bekas.

b) Motif yang beragam, motif yang terdapat pada pakaian bekas yang masih banyak peminatnya adalah motif polos, motif kotak-kotak, garis, atau polka dot.

c) Pakaian berbau, hal ini dikarenakan penempatan pakaian bekas dalam satu ball atau karung, sehingga menimbulkan bau yang tidak sedap.

d) Terdapat bercak warna, hal ini disebabkan karena semua pakaian tertumpuk di satu tempat, bercak ini terkadang berwarna putih pada pakaian warna hitam dan warna kuning pada pakaian warna lainnya.

${ }^{21}$ Hanjoyo Bono Nimpuno, Kamus Besar Bahasa Indonesia, (Jakarta: Pandom Media Nusantara, 2014), 99. 
e) Sedikit kotor dan kusam, hal ini disebabkan karena debu dan kotoran yang menempel pada pakaian selama perjalanan menuju tempat tujuan.

Adapun dampak negatif yang ditimbulkan karena mengkonsumsi pakaian bekas yang berasal dari luar negeri, berdasarkan Peraturan Menteri Perdagangan adalah sebagai berikut:

a) Banyaknya bakteri yang merugikan kesehatan.

Pakaian bekas adalah pakaian yang telah dipakai oleh orang lain sebelumnya, yang tidak jelas bagaimana kondisinya terbebas atau tidaknya dari penyakit, lalu barang tersebut didatangkan dari luar negeri dan tertumpuk dengan pakaian bekas yang lain dalam satu kontainer. Tanpa adanya kebersihan yang layak, pakaian bekas sudah pasti mengandung banyak penyakit yang dapat menyebar, seperti gatal-gatal, panu, kurap, bahkan tidak menutup kemungkinan dapat menyebarkan penyakit gonore kronis yang sulit untuk didiagnosa. Gonore kronis adalah suatu penyakit yang ditularkan melalui hubungan seksual. Apabila tidak diobati, maka infeksi akut ini dapat menyebabkan kronis dan menjalar keseluruh organ tubuh lainnya.

b) Pakaian bekas menyebabkan pemutusan hubungan kerja industri tekstil. 
Ada dua instrumen perlindungan yang seharusnya diperhatikan pemerintah. Pertama, perlindungan pra-pasar, yaitu pemeriksaan produk sebelum masuk pasar, dan harus melalui proses standarisasi. Kedua, kontrol pasca pasar, setelah barang masuk ke pasar, seharusnya mekanisme kontrol tetap berjalan. Jika suatu barang yang beredar tidak sesuai dengan standar yang telah ditetapkan maka barang itu harus ditarik dari pasar. Apabila mekanisme kontrol yang bagus dari pemerintah tersebut dapat menjamin bahwa barang yang beredar di pasaran steril dari bahan-bahan yang berbahaya bagi kesehatan masyarakat. ${ }^{22}$

Perlambatan ekonomi nasional mendorong Pemutusan Hubungan Kerja (PHK) di industri padat karya, khususnya industri tekstil. Selain itu, arus deras barang impor ilegal dengan harga yang murah dan kadang berkualitas sangat rendah menjadi faktor pemicu putusnya hubungan kerja para buruh tersebut.

c) Industri dalam negeri mati

${ }^{22}$ Agus Budianto, Formalin Dalam Kajian UU Kesehatan; (UU Pangan dan UUPerlindungan Konsumen) Al-'Adalah Jurnal Hukum Islam, (Fakultas Syariah IAIN RIL, Vol.9, No.I, Juni 2010), 160 
Serbuan yang dilakukan para masyarakat untuk membeli pakaian bekas yang berasal dari luar negeri ini tidak hanya masalah defisit neraca perdagangan saja, namun hal ini membuktikan bahwa lemahnya daya saing industri dalam negeri. Salah satu industri yang terpukul karena impor pakaian bekas adalah industri Garmen. Industri Garmen adalah industri yang memproduksi pakaian jadi dan perlengkapan pakaian. Industri tersebut merupakan penyumbang devisa terbesar bagi negara setelah minyak dan gas bumi (migas).

d. Pakaian bekas yang diimpor dari luar negeri termasuk barang yang ilegal

Walaupun para penjual mencari rezeki dengan jalan yang halal karena tidak menyembunyikan cacat atau aib yang terdapat dalam pakaian tersebut, namun cara memperoleh pakaian bekas ini yang tidak dibenarkan, karena pakaian-pakaian tersebut didatangkan ke dalam wilayah Negara Kesatuan Republik Indonesia dengan cara yang ilegal dan telah dilarang peredarannya oleh pemerintah Indonesia. Pakaian-pakaian bekas tersebut didatangkan dari luar negeri dengan cara masuk ke pelabuhan-pelabuhan kecil yang tidak melalui izin pemerintah setempat. Namun, dengan wilayah pesisir Indonesia yang begitu luas, maka pengawasan yang dilakukan 
pemerintah menjadi tidak maksimal, sehingga pakaian bekas ilegal tersebut menjadi bebas masuk ke wilayah Negara Republik Indonesia.

\section{Penutup}

Berdasarkan hasil pembahasan di atas, dapat disimpulkan bahwa: pertama, jual beli pakaian bekas tidak melanggar aturan syariat Islam, dengan terpenuhinya segala rukun dan syarat jual beli. Kedua, meskipun tidak dapat penyimpangan secara syariat, namun beberapa hal perlu untuk dipertimbangkan, yaitu aspek kesehatan dan kebersihan bagi para pembeli baju bekas, serta pemutusan hubungan kerja pada industri produksi baju diakibatkan dengan maraknya jual beli pakaian bekas.

\section{Daftar Pustaka}

A. Djazuli, 2010. Kaidah-Kaidah Fikih: Kaidah-Kaidab Fikih dalam Menyelesaikan Masalab-Masalah Yang Praktis, Cet. 3. Jakarta: Kencana Preneda Media Group.

Afif, Mufti “Tabungan: Implementasi Akad Wadi'ah atau Qardh”, Jurnal Hukum Islam, 2. Desember, 2014. 
Ahmad Mustofa et.al., 2014. Reorientasi Ekonomi Syariah. Yogyakarta: UII Press.

Al Arif, M. Nur Rianto. 2012. Dasar-Dasar Ekonomi Islam, Cet. II. Bandung: Alfabeta.

Al-Ghazi, Muhammad bin Qosim. 2016. Fath al Qorib al-Muïb, Juz 1. Kediri: Zamzam Sumber Mata Air Ilmu.

Anshori, Abdul Ghofur. 2009. Perbankan Syariah di Indonesia. Yogyakarta: Gadjah Mada University Press.

Basir, Ahmad Azhar. 1993. Azqa-Azas Muamalah. Yogyakarta: UII Press.

Boeree, C. George. 2014. Psikologi Sosial. Jogjakarta: Primashopie.

Fatoni, Siti Nur. 2014. Pengantar Ilmu Ekonomi. Cet. I. Bandung: Pustaka Setia.

Hakim, Rahmad. "Islamisasi Ekonomi Madð̧hab Mainstream: Tinjanan, Model dan Implikasi”, Iqtishodia: Jurnal Ekonomi Syari’ah, Vol. 1, No.1, (Maret, 2016), 81-82.

Haris, Muhammad. 2015. "Analisis Faktor-Faktor yang Mempengarubi Preferensi Nasabah Terhadap Bank Syariah di DKI Jakarta”, Skripsi. Bogor: Institut Pertanian Bogor.

Karim, Adiwarman A. 2004. Bank Islam, Analisis Fiqh dan Keuangan. Jakarta: PT. Raja Grafindo Persada. 
Mappiare, Andi. 1997. Psikologi Remaja. Surabaya: Usaha Nasional.

Muhamad. 2016. Manajemen Keuangan Syariah, Cet. II. Yogyakarta: UPP STIM YKPN.

Partanto, Pius A. 2001. Kamus Ilmiah Populer. Surabaya: Arkola.

Suwiknyo, Dwi. 2010. Kompilasi Tafsir Ayat-Ayat Ekonomi Islam.

Yogyakarta: Pustaka Pelajar.

Syafe'i, Rachmat. 2001. Fikih Muamalah. Bandung: Pustaka Setia.

Syuhud, Fatih. 2008. Santri, Pesantren dan Tantangan Pendidikan Islam, Cet. II. Karangsuko: Pustaka ALKHOIROT.

Undang-Undang Republik Indonesia Nomor 10 Tahun 1998 Tentang Perbankan.

Wahyu Utami, et.al., "Analisis Pengaruh Religinitas, Kelompok Referensi, dan Motivasi Terbadap Keputusan Menabung di Bank Syariab", Jurnal Wawasan Manajemen, Vol. 3, 1 (Februari, 2015). 